\title{
THE ATMOSPHERIC DYNAMIC EXTREME OF TROPICAL AS AN ANALYSIS OF CLIMATE CHANGE IN INDONESIA
}

\author{
Rahmat GERNOWO ${ }^{*}$ (D), Catur Edi WIDODO ${ }^{1}$ (D), Aris Puji WIDODO ${ }^{2}$ (D)
}

DOI: 10.21163/GT_2020.152.14

\begin{abstract}
:
Variability of rainfall, especially in tropical regions like Indonesia has been an important issue that needs to be studied to find out the effect caused. The phenomenon of the occurrence of a flood is more indicated by the heavy rains fall in the region of Jakarta for a few days. This research aims to analyze the characteristics of heavy rain through the approach of atmospheric dynamic anomaly using the WRF model. The method used in this research was Weather Research and Forecasting (WRF) using the scheme of Kain Fritsch's cumulus parameter. The method of this research was applied to the occurrence of the most extreme rainfall of the data from 2007 and 2015 in Jakarta. The analysis result shows that the extreme rainfall was caused by the growth of rail clouds type of Cumulonimbus. The analysis of atmospheric dynamics and the numeric calculation shows that there has been a growth of extreme rain clouds above Jakarta skies indicating the occurrence of climate change.
\end{abstract}

Key-words: Flood, Could dynamics, Satellite image, Climate change, Cloud model

\section{INTRODUCTION}

Indonesia is a country located in the equator line which astronomically is located between $6 \mathrm{NL}$ - 11 SL and 95 EL - 141 EL. Such location makes Indonesia become a wet tropical country with sufficiently high rainfall. The phenomenon of extreme rainfall is caused more by climate change occurrence, i.e. the occurrence of climate change compared to its long-term average in a certain time. The climate deviation usually comes from non-seasonal climate factors such as the phenomenon of ENSO (El Nino Southern Oscillation).

During ENSO, the transition season starts from rain and drought. In terms of atmospheric dynamics, this is caused by heating of the ocean in the Pacific Ocean region and it occurs annually. It occurs because of Sea Surface Temperature arising between the West and East Pacific Ocean (Aldrian, 2008). The phenomenon of ENSO occurs globally from the sea atmospheric interaction system in the Pacific Region. The influence of ENSO in each region in Indonesia, in general, occurs during the transition season (Siswanto, et al., 2015).

Based on the event of floods occurring from 2002 to 2020 (Table 1), there have been four heavy floods in Jakarta, i.e. on $26^{\text {th }}$ January $-1^{\text {st }}$ February $2002,4^{\text {th }}-14^{\text {th }}$ February $2007,15^{\text {th }}-24^{\text {th }}$ January 2013 , and $9^{\text {th }}-12^{\text {th }}$ February 2015 , and $31^{\text {st }}$ December $-2^{\text {nd }}$ January 2020 . Precursors of flood in Jakarta were mainly caused by extreme rainfall, land subsidence, and the contribution of the rising sea surface level (Sakurai et al., 2005, Abidin et al., 2015).

Based on the above research and the data of flood occurrence, it has been important to discuss the comparison of analysis of clouds growth, extreme rainfall, and flood occurrence in Jakarta in the maximum extreme time within the period of 2007 to 2015 seen based on the effect of the inundated width. The analysis of the heavy flood historical atmospheric dynamic in Jakarta becomes the evidence that climate change is happening.

\footnotetext{
${ }^{1}$ Physics Department, Faculty of Sciences and Mathematics, Diponegoro University, Semarang, Indonesia, gernowo@yahoo.com, catur.ediwidodo@gmail.com

${ }^{2}$ Informatics Department, Faculty of Sciences and Mathematics, Diponegoro University, Semarang, Indonesia, arispw@gmail.com
} 
Tabel 1.

Extreme rainfall data and affected areas in Jakarta.

\begin{tabular}{|l|l|l|l|l|l|}
\hline Date of Occurrence & $\begin{array}{l}\mathbf{2} \text { February } \\
\mathbf{2 0 0 2}\end{array}$ & $\begin{array}{l}\mathbf{2} \text { February } \\
\mathbf{2 0 0 7}\end{array}$ & $\begin{array}{l}\mathbf{1 7} \text { January } \\
\mathbf{2 0 1 3}\end{array}$ & $\begin{array}{l}\text { 11 February } \\
\mathbf{2 0 1 5}\end{array}$ & $\begin{array}{l}\text { 1 January } \\
\mathbf{2 0 2 0}\end{array}$ \\
\hline Highest Rainfall $(\mathrm{mm} /$ day) & 168 & 340 & 100 & 277 & 377 \\
\hline RW Flooded & 353 & 955 & 599 & 702 & 390 \\
\hline Flooded Area $\left(\mathrm{km}^{2}\right)$ & 168 & 455 & 240 & 281 & 156 \\
\hline Strategic Area & Yes & Yes & Yes & Yes & Yes \\
\hline Number of Refugees & 154.270 & 276.300 & 90.913 & 45.813 & 36.445 \\
\hline $\begin{array}{l}\text { Low tide> 95\% inundation } \\
\text { (days) }\end{array}$ & 6 & 70 & 7 & 7 & 4 \\
\hline Data Source; BPBD, Bappenas, BMKG, Open Data Jakarta & 7 \\
\hline
\end{tabular}

\section{STUDY AREA AND DATA}

This research area, including the Jakarta and surrounding areas affected by flooding in 2007 and 2015. As shown in Fig.1 is a morphological map of the Jakarta area which is implemented from the scaling of the terrain height $(\mathrm{m})$.

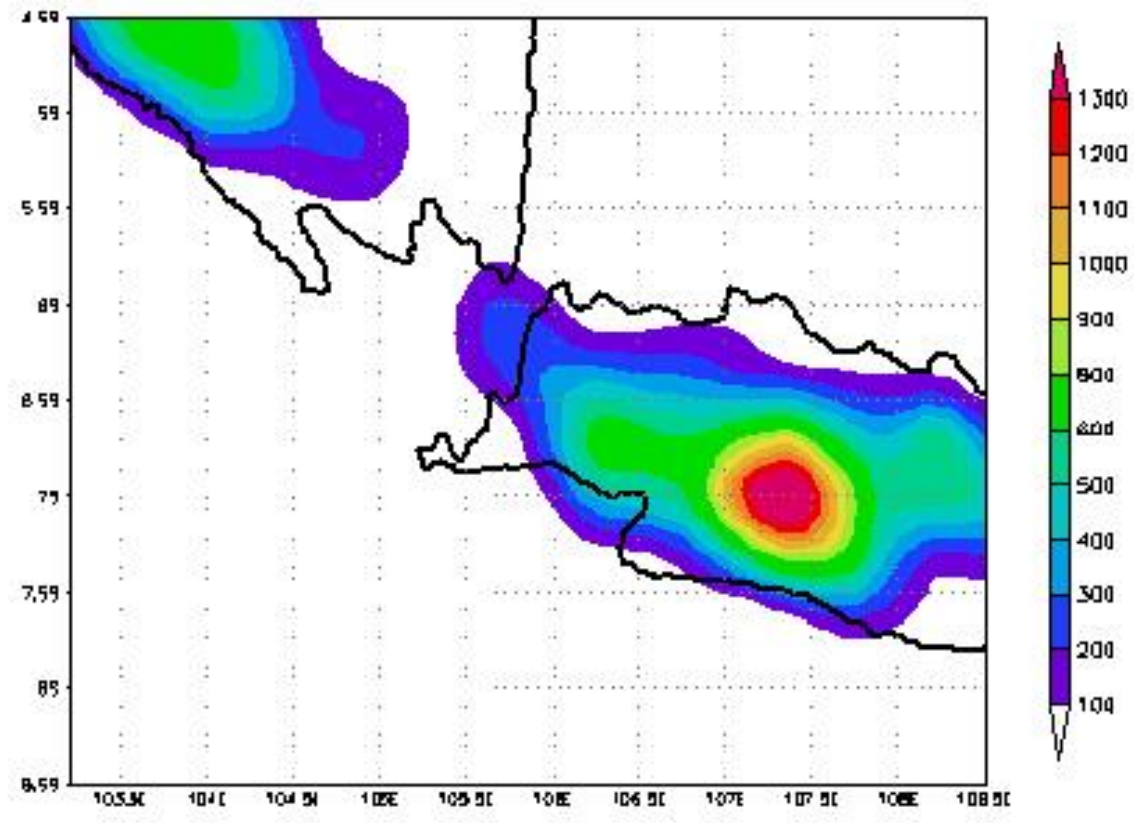

Fig. 1. Topographic map of the study area based on the results of Terrain height (m).

\subsection{Data Global}

As mentioned above, as the data input on the WRF model, FNL (Final Global Data Assimilation System) data is needed, it constitutes operational data from National Centres for Environmental Prediction (NCEP). Data NFL is located at $90 \mathrm{NL}-90 \mathrm{SL}, 0 \mathrm{EL}-360 \mathrm{E}$ with the resolution of $1^{\mathrm{O}} \mathrm{x}$ $1^{\mathrm{O}}$, with the format data is WMO GRIB1 data available for about 6 hours for 00Z, 06Z, 12Z, and 18Z every day. 
A preliminary simulation was carried out to see the pattern of convection growth and the pattern of rainfall when extreme rainfall 2007 and 2015 occurred. Simulation regions were divided into three domains; domain 1 resolution $30 \mathrm{~km}$, domain 2 resolution $10 \mathrm{~km}$, domain 3 resolution $5 \mathrm{~km}$. Domain 1 and 2 used 2 direction nesting, while domain 3 ran separately (offline nesting). micro-physics parameterization scheme determination was carried out using the WRF scheme of Single-Moment 6Class (WSM6) (Hou et al., 2016). This was carried out based on the previous research and the convection process assumption could be determined by the micro-physics process.

\subsection{Sonde Data Radio and Other Data}

Determining the limit required and the preliminary requirements are highly necessary, therefore, the result obtained was the pattern representing the condition of the research area, in this case Jakarta. Preliminary treatment from FNL data to obtain limit requirement and preliminary requirements that go along with Jakarta, i.e. by validating FNL data with radiosonde.

Radiosonde data representing Jakarta was obtained from BMKG (Meteorology Climatology and Geophysics Council) observation station, Cengkareng-Jakarta (-6, 110 SL - 106,650 EL), within the duration of January-February 2007, and January-February 2015. Other data used in this research covered weather data within a daily period for January-February 2007 and 2015.

\section{METHODOLOGY}

\subsection{Weather Research and Forecast Model}

WRF Model has developed an advanced generation of forecasting models of mesoscale assimilation systems to help to understand and forecast the mesoscale system about the rain. WRF model is the newest model developed from model MM5 (Mesoscale Model 5) applied in various issues and it covers some advantages such as (Skamarock, et al., 2005):

1. The model uses vertical coordinate following the terrain, hydrostatic pressure with constant pressure surface peak model with grid horizontal from Arakawa.

2. The model is compatible either for ideal application or real data with various choices of the lateral condition and upper limit.

3. Micro physics calculation

4. Parameterization of cumulus.

The basic equation on the atmospheric circulation model consists of a partial differential equation, for the completion of the dynamic issue. Several input variables are wind velocity component $u$ and $v$, temperature T, specific moisture $q$, and surface pressure $p s$.

Hydrostatic equation

$$
\frac{\partial \Phi}{\partial \eta}=-\frac{R_{d} \mathrm{~T}_{v}}{P} \frac{\partial p}{\partial \eta}
$$

Thermodynamic Equations

$$
\frac{\partial T}{\partial t}=-\frac{u}{a \cos \theta} \frac{\partial T}{\partial \lambda}-\frac{v}{a} \frac{\partial T}{\partial \theta}+\frac{k T_{v} \omega}{(1+(\delta-1) q) p}+\mathrm{P}_{T}+\mathrm{K}_{T}
$$

Moisture equations

$$
\frac{\partial q}{\partial t}=-\frac{u}{a \cos \theta} \frac{\partial q}{\partial \lambda}-\frac{v}{a} \frac{\partial q}{\partial \theta}-\eta \frac{\partial q}{\partial \eta}+\mathrm{P}_{q}+\mathrm{P}_{q}
$$


Equation continuity

$$
\frac{\partial}{\partial \eta} \frac{\partial p}{\partial t}+\nabla \cdot\left(V_{h} \frac{\partial p}{\partial \eta}\right)+\frac{\partial}{\partial \eta}\left(\eta \frac{\partial p}{\partial \eta}\right)=0
$$

Definition of $\xi$

$$
\begin{aligned}
& \xi=\frac{1}{a \cos \theta}\left(\frac{\partial v}{\partial \lambda}-\frac{\partial}{\partial \theta}[\cos \theta u]\right) \\
& \text { And } E=\frac{1}{2}\left(u_{2}+v_{2}\right)
\end{aligned}
$$

Where $\Phi(=g z)$ is a geopotential factor, $f=2 \Omega \sin \theta$ the Coriolis parameter, $\Omega$ is the angular velocity, $a$ is the radius of the earth, $T_{v}=(1+(\varepsilon-1-1) q), T$ is a virtual temperature, $R_{d}$ is the gas constant for dry air, $R_{v}$ is the gas constant for water vapor, $k=R_{d} / C_{p d}$ with $C_{p d}$ is the specific heat for dry air at constant pressure, $\delta=C_{p v} / C_{p d}$ with $C_{p v}$ is the specific heat for dew air at constant pressure and $\omega$ is the velocity of vertical pressure.

\section{RESULTS AND DISCUSSIONS}

Atmospheric dynamic analysis of extreme rainfall event in Jakarta was caused by weather anomaly change, the existence of MJO (Madden Julian Oscillation) periodicity and IOD (Indian Oscillation Dipole) which were the dominant effects as flood precursor (Aldrian, 2008), in the period of 2007 and 2015, however, from the climate analysis data showed growth to the dominant direction (Report BMKG, 2015).

A low-pressure anomaly occurred in Indies Ocean as shown in (Fig. 2) was the characteristics of a flood event on $11^{\text {th }}$ February 2015 (Fig. 2a) and $2^{\text {nd }}$ February 2007, like in (Fig. 2b). From the streamline map, it could be seen that there was convergence and wind divergent area (shoreline), this triggered the growth of convective clouds that could produce heavy rain in the areas of wind meeting. Such low-pressure synoptic effect dominated the occurrence of extreme rainfall, therefore, extraordinary rainfall that caused a flood in 2015 and 2007 in Jakarta was dominated by a local factor of clouds growth. Regional factor showed Asian cold monsoon that had been active, vibrant that triggered the formation of rain clouds which had the potential to occur in Java island in general and specifically in Jakarta (Gernowo et al., 2017, Masouleh et al., 2019).

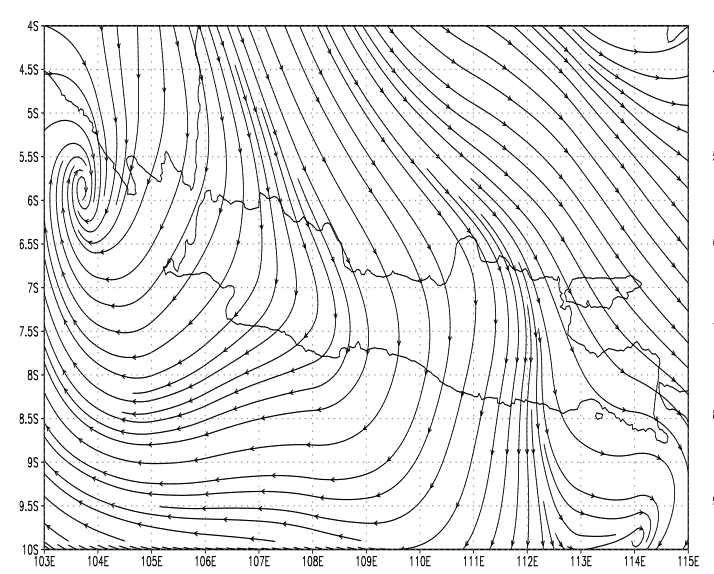

a)

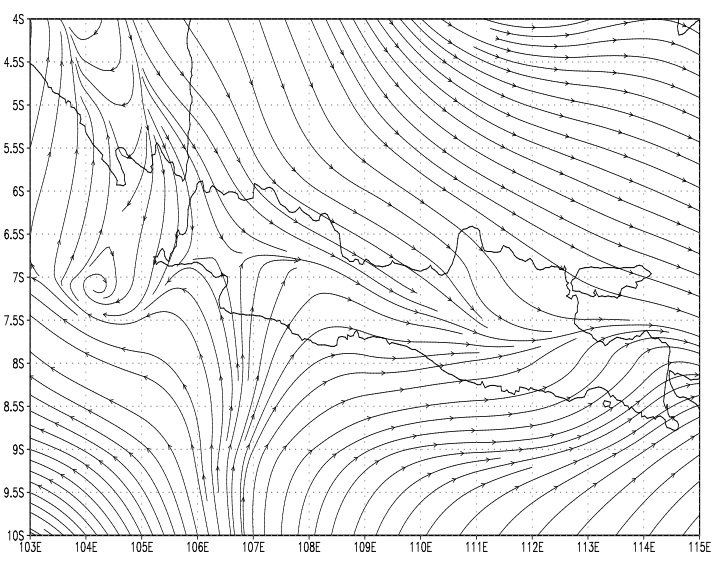

b)

Fig. 2. The wind (vortex) is from $9^{\text {th }}$ to $12^{\text {th }}$ February $2015-\mathbf{a}$ ), the wind (vortex) is from $25^{\text {th }}$ January to $5^{\text {th }}$ February $2007-\mathbf{b}$ ). 
This study was analyzed based on data AVN from $9^{\text {th }}$ to $12^{\text {th }}$ February 2015 , and from $25^{\text {th }}$ January to $5^{\text {th }}$ February 2007, in Jakarta. The 2007 analysis was based on the previous result (Gernowo et al., 2018, Hidayat et al., 2017 and Diaz et al., 2001), as for the analysis in 2015 based on BMKG data (Report BMKG, 2015). Absolute vorticity on $11^{\text {th }}$ February 2015, between the Java Sea and Indies Ocean, there had been negative vorticity anomaly in Java island and it ended on $12^{\text {th }}$ February 2015. It proved that tropical convection activities in the ocean were more active with sufficiently big variations. (Roxana and Wajsowicz, 2005, Roy et al., 2019, Siswanto et al., 2015).

Vorticity anomaly dynamic in February 2015 became maximum in Java on $11^{\text {th }}$ February 2015 and ended on $12^{\text {th }}$ February 2015 . Then on $1^{\text {st }}$ February 2007, negative vorticity anomaly occurred in several parts of Java and ended on $2^{\text {nd }}$ February 2007 as shown (in Fig. 3a and Fig. 3b). This proved that tropical convection activities above the ocean were more active with big variation compared to the land especially in Jakarta (Masouleh et al., 2019 and Aldrian, 2008). Local atmospheric circulation caused the clouds' growth patterns in Jakarta. It showed that the change of anomaly of convection clouds growth in February 2015 and February 2017 was influenced by local atmospheric dynamics, regionally and globally caused by climate change effects.
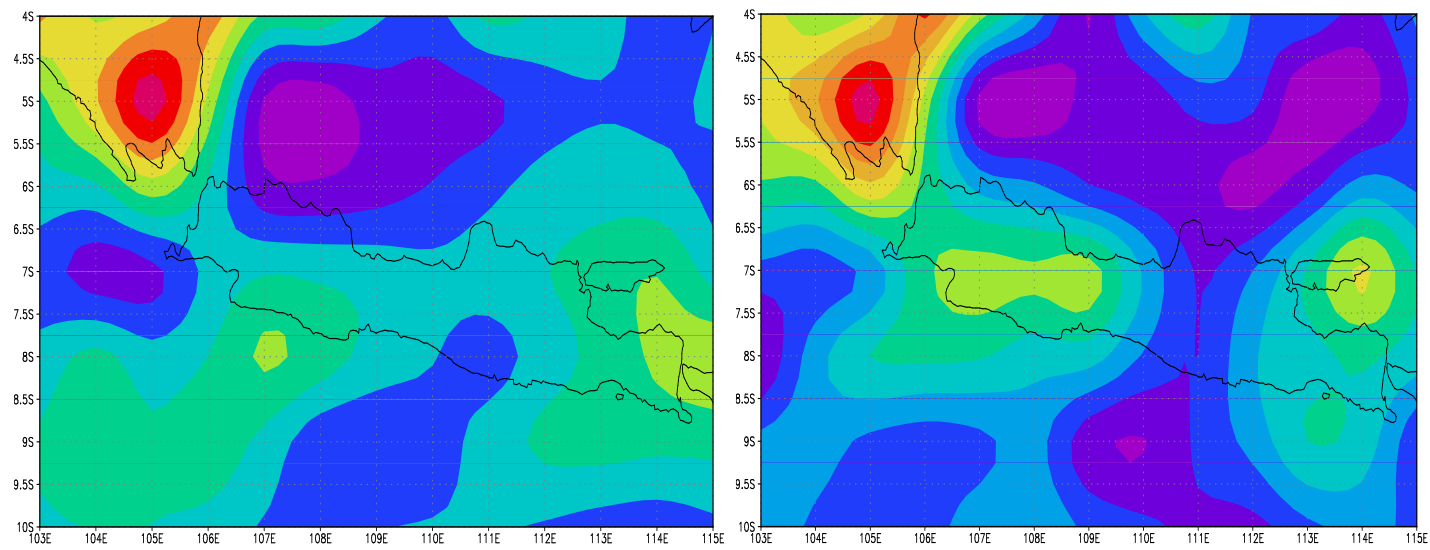

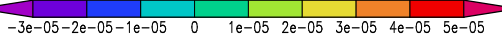

a)
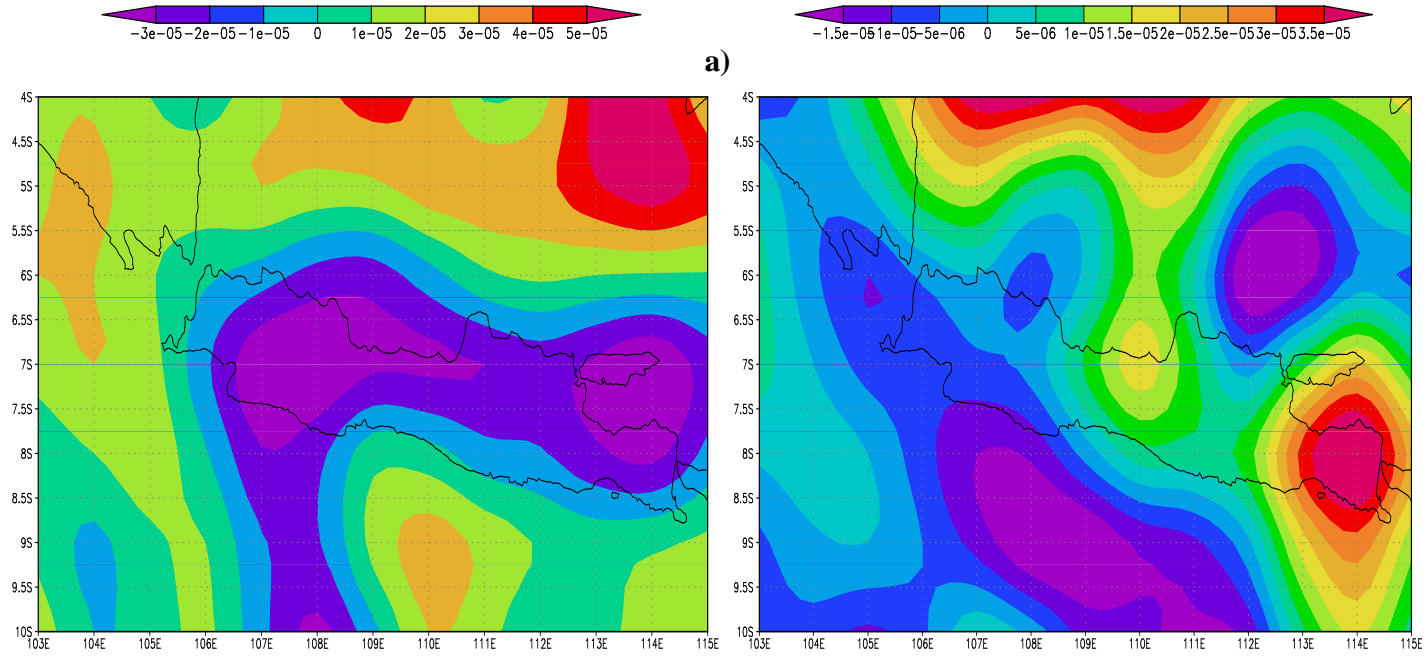

GrRSS: COLA/GES

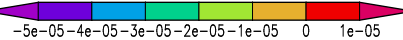

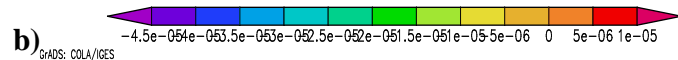

Fig. 3. Wind divergence of DKI-Jakarta on $11^{\text {th }}$ February 2015 and $2^{\text {nd }}$ February $2007-\mathbf{a}$ ), absolute Vorticity [m/s] of DKI-Jakarta Date on $11^{\text {th }}$ February 2015 and $2^{\text {nd }}$ February 2007 from data NCEP/NCAR - b). 


\subsection{Analysis Model Weather Regional Forecast (WRF)}

The atmospheric dynamic numeric analysis is quantitative simulation research to explain the occurrence of extreme rainfall in January/February 2007 and 2015 in the event of a flood in Jakarta. In this research WRF modelling System version 2 was used, non-hydrostatic regional scale or mesoscale model (Skamarock, 2005, Thompson et al., 2016). The application technique of model WRF, first was determining domain area, this was to carry out downscaling of the research area (Skamarock et al., 2005). The application of the model in this research covered the microphysics process, cumulus parameterization, the selection width, or area of research region was meant to obtain a sufficiently realistic result representing the actual condition. In determining the limit of the research area, three nesting stages were used to downscale the data global NCEP-FNL, this was to reach the clouds' growth within the radius of $3 \mathrm{~km}$ to horizontal direction connecting the smallest region. The simulation process of domain 1 and 2 was carried out at the same time within a single WRF model system, as for domain 3, it was carried out using Ndown.exe command from model WRF. The resolution of the three domains, i.e. domain 1 with resolution $30 \mathrm{~km}$, domain 2 with resolution $10 \mathrm{~km}$, domain 3 resolution $5 \mathrm{~km}$. The domain region of the simulation could be seen in Fig. 4 .

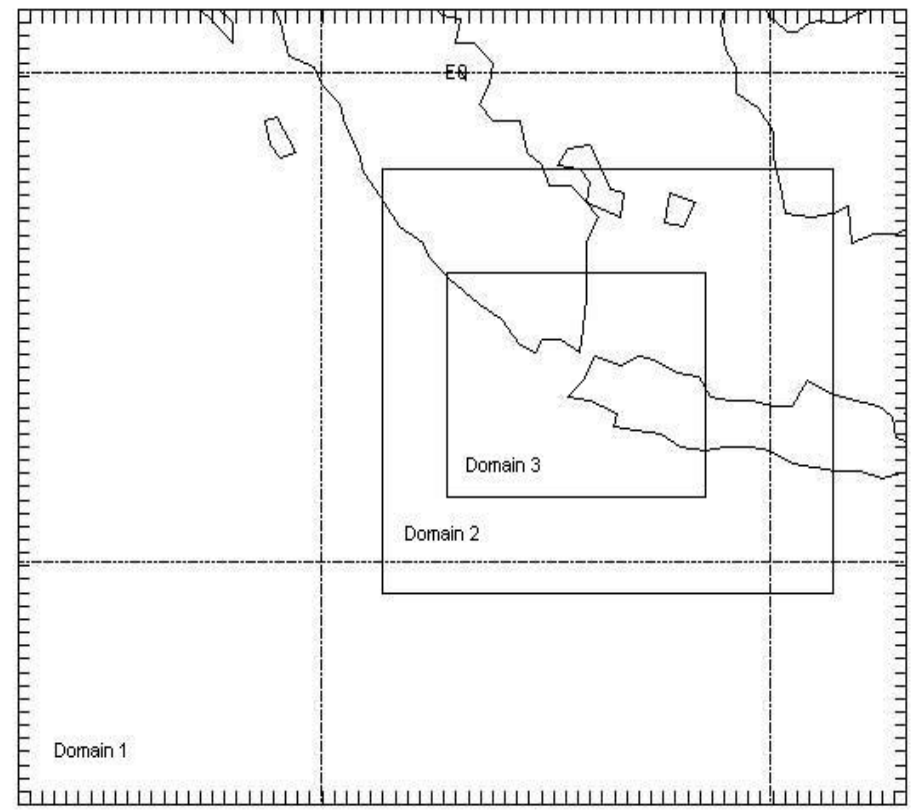

Fig. 4. Downscaling the research area into 3 domains.

\subsection{Limit Requirements and Initial Requirement Model}

The determination of the initial condition and limit condition in a model is very important since it will determine the output validity produced. The initial input data functions as the initial condition and limit condition used for the WRF model were determined from the FNL data, data validity was carried out through the treatment of comparing FNL data with upper air measurement (radiosonde) in the chosen station. Variable compared including air component of $u$ and $v$ in $\mathrm{m} / \mathrm{s}$ and the temperature in ${ }^{\mathrm{O}} \mathrm{K}$ (degree Kelvin) as shown in Fig. 5., it showed the profile of radiosonde data vertical and FNL on $2^{\text {nd }}$ February 2007, at 00 UTC and $11^{\text {th }}$ February 2015, which had not been filtered. Data from the radiosonde Cengkareng Station with the assumption representing the research region of Jakarta.

The comparison of two vertical profiles in Fig. 5a and Fig. 5b showed the assimilation process of FNL data with radiosonde data. It showed that data assimilation had succeeded to be done so that radiosonde data was included in FNL data, meanwhile, to obtain a radiosonde data filtered process, filtering could be done. There were some options of filtering presented in the WRF model, Fang's research, (2006) using the Lancos filter to obtain a good result. 

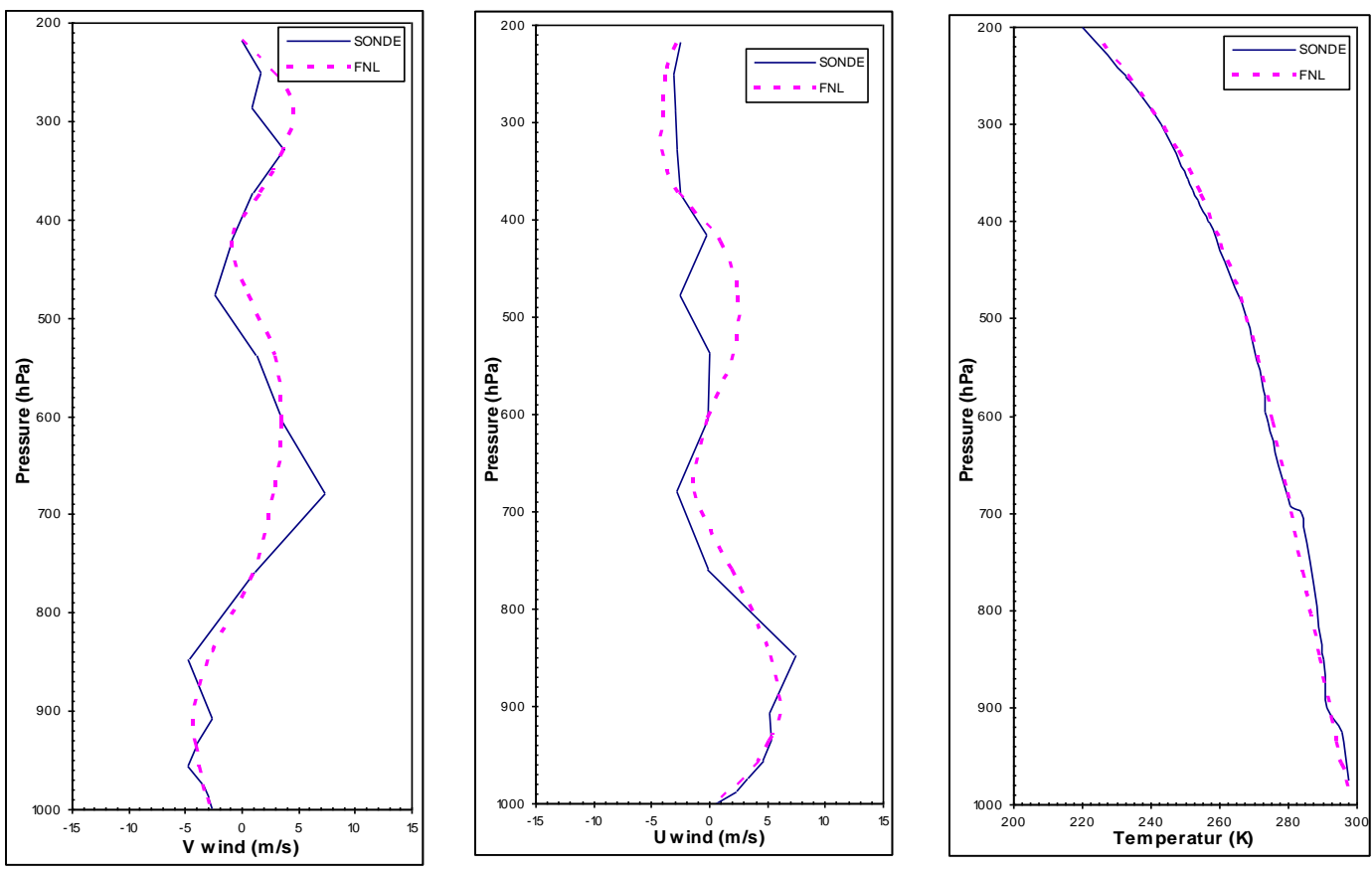

a)
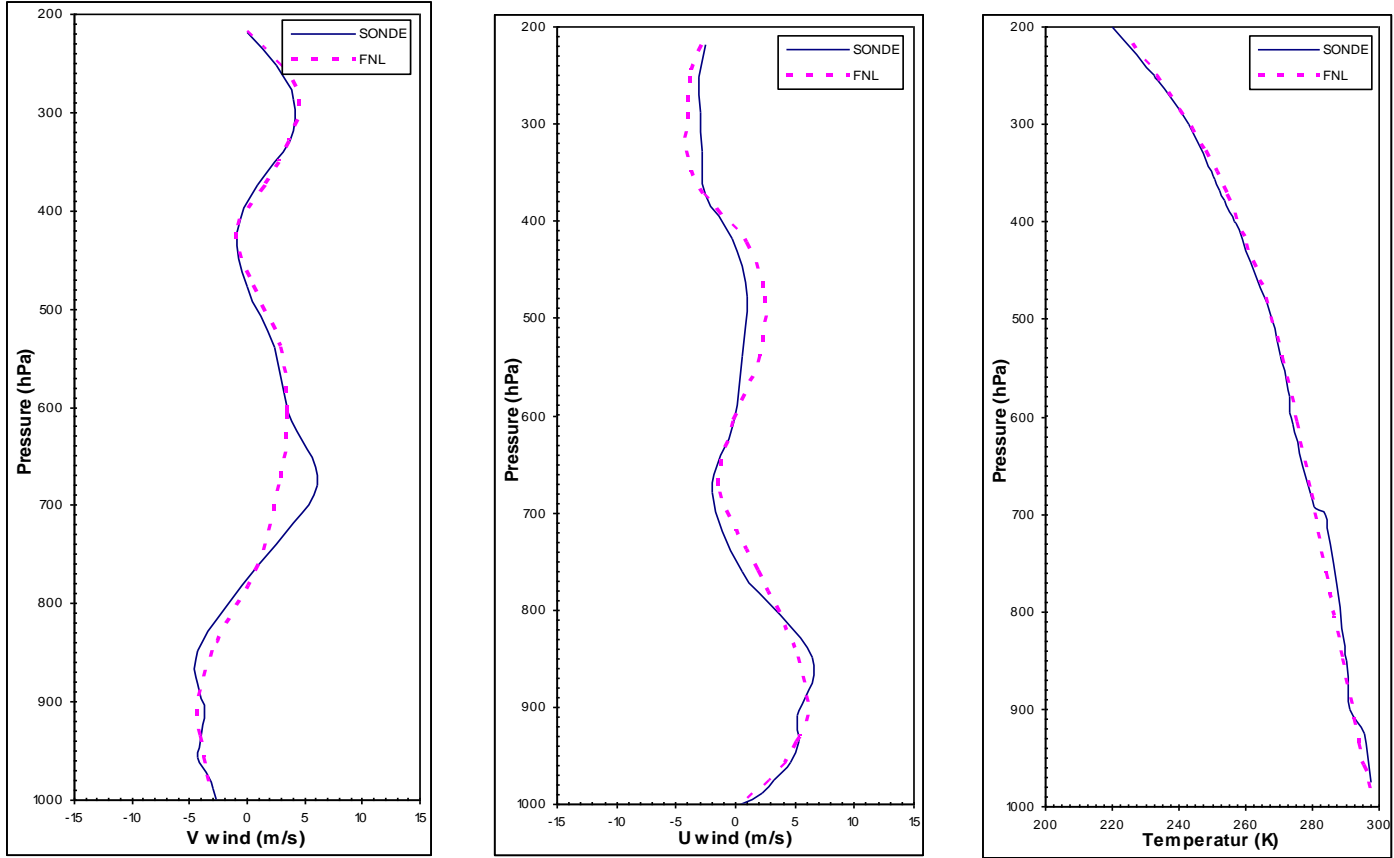

b)

Fig. 5. Validation of wind $V(\mathrm{~m} / \mathrm{s})$ and $U(\mathrm{~m} / \mathrm{s})$ and Temperature $(\mathrm{K})$ FNL data with radiosonde data Cengkareng-Jakarta station data on $2^{\text {nd }}$ February 2007 at $\left.00 \mathrm{UTC}-\mathbf{a}\right)$;

validation of wind $\mathrm{V}(\mathrm{m} / \mathrm{s})$ and $U(\mathrm{~m} / \mathrm{s})$ and Temperature $(\mathrm{K})$ FNL data with radiosonde data of CengkarengJakarta station data on $11^{\text {th }}$ February 2015 at 00 UTC - b). 


\subsection{Cloud Simulation}

To see the pattern of clouds growth, the QCLOUD model was used to calculate the clouds in the WRF model. From the result of model simulation for horizontal clouds (Fig. 6.) it could be analyzed that the maximum condition occurred after the data on $2^{\text {nd }}$ February 2007, at 00 UTC and $11^{\text {th }}$ February 2015, as a model in entering the data. The growth of convective clouds would produce convective rainfall produced from the convection current for the surface heating by sunlight radiation, wind convergence, or because of updraft physical drive when the wind passed through the mountainous area. Convective rainfall had high intensity compared to stratiform rainfall, it occurred in a limited space scale between 10-20 km2 depended on the convection cell dimension itself (Cooley et al., 2007, Gernowo, 2018). In the tropical area, the occurrence of convective clouds and convective rain was very dominant, for the land area, it happened in the afternoon while for convection maritime area, it occurred at noon supported by sea convection during the night.
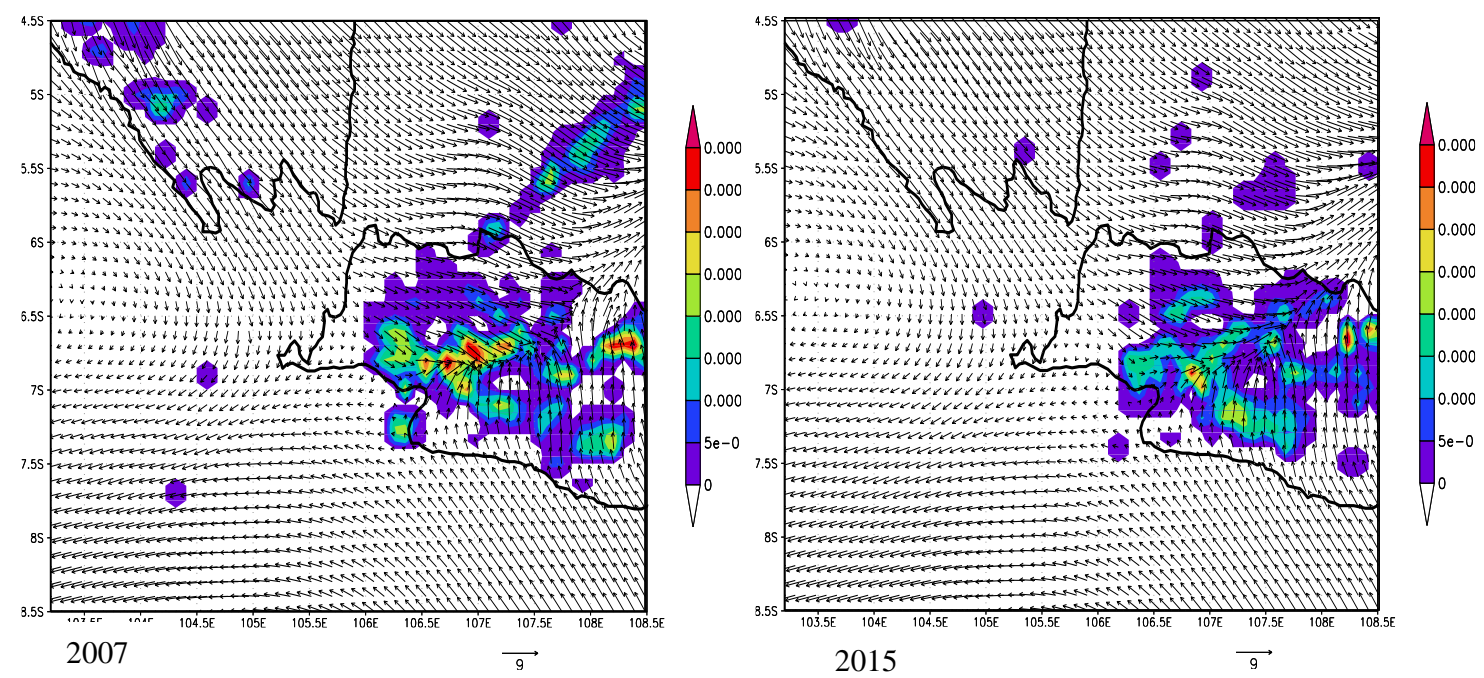

Fig.6. Horizontal rain cloud simulation $\left(\mathrm{kg} / \mathrm{kg}\right.$ ) data for $2^{\text {nd }}$ February 2007 , and $11^{\text {th }}$ February 2015 , at 00 UTC Convective cloud growth patterns occur above Jakarta and its surroundings.

The Cloud simulation result for Jakarta region showed high growth, it indicated the occurrence of high-intensity rainfall. The pattern of this growth showed that the period of extreme rainfall on $2^{\text {nd }}$ February 2007, and $11^{\text {th }}$ February 2015, were caused more by local atmospheric dynamic influence, i.e. the existence of thermal convection anomaly. Another analysis for this case was the occurrence of sea-land wind circulation that would boost the development of convection cells above the beach of Jakarta that had the potential to produce heavy rain. Based on the above analysis from the atmospheric dynamics and numeric clouds simulation, showed that the flood disaster around Jakarta and the tropical area was generally caused more by the growth of extreme convective clouds. This became obligatory to enter climate factors in every plan of natural disaster countermeasure as well as generally in the sustainable development plan especially in the tropical area (Prasetyo et al., 2018).

\section{CONCLUSIONS}

The occurrence of extreme rainfall in Jakarta region from the explanation that had been conveyed, it could be concluded that the extreme weather event that caused a huge flood in February 2007 and 2015 was influenced by various regional and local meteorological factor. Also, weather disturbance causing the occurrence of heavy rain and flood was caused by mechanical and thermal weather disturbances. Where mechanical condition meant was the convergence of under layer, while this 
thermal factor was signed by the existence of advection of cold air from Asian land or what was known as Cold Surge.

Based on the analysis of FNL data numeric and radiosonde, in Jakarta in 2007 and 2015, based on the model review, it showed the convective clouds growth result was quite extreme, FNL data scenario assimilating with radiosonde data in the area of study. The tendency of this atmospheric dynamic improvement effect in the tropical area indicated the occurrence of climate change.

\section{ACKNOWLEDGMENTS}

The authors would like to express heartfelt thanks to Non-APBN OPOC Program Research Diponegoro University, 2019/2020 Budgeting for providing financial support.

\section{R E F E R E N C E S}

Aldrian E. (2008) Dominant Factor of Jakarta's Three Largest Flood. Journal Hidrosfer Indonesia, 3, 105-112.

Abidin H. Z., Andreas H., Gumilar I., and Wibowo I. R. (2015) On the correlation between urban development, landsubsidence, and flooding phenomena in Jakarta. Proc. IAHS, 370, 15-20, 2015proc-iahs.net/370/15/2015/ doi:10.5194/piahs-370-15-2015.

Cooley,D., D.Nychka, and P. Naveau (2007) Bayesian spatial modeling of extreme precipitation return levels. $J$. Amer.Stat.Assoc.,102, 824-840, https://doi.org/10.1198/016214506000000780.

Diaz, H.F., M.P. Hoerling, and J.K. Eischeid (2001) ENSO variability, teleconnections, and climate change. Int., J. Climatol, 21, 1845-1862.

Gernowo R., Adi K., Yulianto T., Seniyatis S., and Yatunnisa A.A. (2018) Hazard Mitigation with Cloud Modelbased rainfall and Convective data. Journal of Physics: Conference Series, 1025 (1), 012023.

Gernowo R., Adi K., and Yulianto T. (2017) Convective Cloud model for Analyzing of Heavy rainfall of Weather Extreme at Semarang Indonesia. Advanced Science Letter, 23(7), 6593-6597.

Hou T., Lei H., Yang J., Hu Z., Feng Q. (2016) Investigation of riming within mixed-phase stratiform clouds using Weather Research and Forecasting (WRF) model. Atmospherics Research Journal, 178-179, 291303.

Hidayat R., Juniarti M.D., and Ma'rufah U. (2018) Impact of La Niña and La Niña Modoki on Indonesia rainfall variability. IOP Conf. Ser.: Earth Environ. Sci. 149, 012046

Masouleh Z.P., Walker D.J. and Crowther J.M. (2019) A Long-Term Study of Sea-Breeze Characteristics: A Case Study of the Coastal City of Adelaide. J. Appl. Meteor. Climatol. (2019) 58(2), 385-400. https://doi.org/10.1175/JAMC-D-17-0251.1

Prasetyo Y., Yuwono B. D., and Ramadhanis Z. (2018) Spatial Analysis of Land Subsidence and Flood Pattern Basedon DInSAR Method in Sentinel Sar Imagery and WeightingMethod in Geo-Hazard Parameters Combination in NorthJakarta Region. IOP Conf. Series: Earth and Environmental Science, 123, 012009.

Roxana C., and Wajsowicz (2005) Forecasting extreme events in the tropical Indian ocean sector climate. Journal dynamics of atmospheres, and ocean, pp. 1-15.

Roy I., Tedeschi R.G., and Collins M. (2019) ENSO teleconnections to the Indian summer monsoon under climate changing. International Journal of Climatology, 39 (6), 3031-3042.

Sakurai N., Murata F., Yamanaka M.D., Mori S., Hamada J.I., Hasiguchi H., Tauhid Y.I., Sribimawati T., Suhardi B. (2005) Diurnal Cycle of Cloud System Migration over Sumatera Island. Journal of the Meteorological, 83 (5).

Skamarock W.C., Klemp J.B., Dudhia J., Gill D.O., Barker D.M., Wang W., and Powers J.G. (2005) A Description of the Advanced Research WRF Version 2, Mesoscale and Microscale Meteorology Division, National Center for Atmospheric Research Colorado USA.

Siswanto, Geert J. V. O. B., Gerald V.D.S., Lende R.K., and Bart V.D.H. (2015) Trends in High-Daily Precipitation Events in Jakarta and Flooding of January (2014) Special Supplement to the Bulletin of the American Meteorological Society, 96 (12).

Meteorology Climatology and Geophysics Council (BMKG), Climate Analysis (2015) Progress report, https://www.bmkg.go.id/

Thompson G., Tewari M., Ikeda K., Tessendorf S., Weeks C., Otkin J., Kong F. (2016) Explicitly-coupled cloud physics and radiation parameterizations and subsequent evaluation in WRF high-resolution convective forecasts. Atmospherics Research Journal, 168, 92-104. 